\title{
Village Accounting Reconstruction Methodology Based on the Kingdom of God
}

\section{Ivana Nina Esterlin Barus}

Universitas 17 Agustus Samarinda, Jl. Ir. H. Juanda, No.80 Universitas 17 Agustus 1945, Air Hitam, Kec. Samarinda Ulu, Kota Samarinda, Kalimantan Timur 75123, Indonesia

wiliva.couple@gmail.com

\section{ARTICLE INFO}

Article history

Received 6 June 202

Revised 11 August 2021

Accepted 20 August 2021

Keywords

Kingdom of God;

Martin Luther;

New Life;

Village accounting.

\section{ABSTRACT}

This article aims to develop a research methodology in the field of village accounting that is religious and spiritual in nature to redirect village accounting practice to its holiness and religiousity simultaneously. The construction of a refined village accounting methodology was carried out through a study of the financial management of the Kingdom of God according to the Church Reform Leader, Martin Luther and historical analysis on the practice of village accounting. The result is a village accounting research methodology with religious and spiritual principles of the Kingdom of God. New Life as a methodology that will be constructed to restore the purity of village accounting, clearly rejects the impure, as a powerful way to improve the financial management system for a better governance. Village accounting based on the kingdom of God is based on the loyal principle: to organize, to receive, and to faithfully sow. In practice, this principle will be able to realize the ideals of the Indonesian people to break free from the confine of capitalism and neoliberalism.

This is an open access article under the CC-BY-SA license

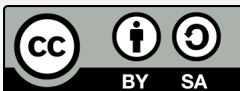

\section{Introduction}

My village that I love.

Idol of my heart.

Father and Mother's place.

And my relatives.

I won't forget it easily.

It's not easy to get separated.

I always miss.

My beautiful village.

(My Village (Desaku), by L. Manik)

The song 'Desaku' describes a village that is loved by its people. The writer's pride in his village is reflected in this song's lyrics. The village where he was born, was also the place where parents and relatives gather to live and rejoice. There is no caste difference there. This song depicts the possibility of Manik having migrated to another area far from 
his home village, but was still longing to return to his village. Such is the atmosphere of a beautiful village, where kinship and mutual cooperation exists. Yet, this atmosphere may not exist in terms of village fund management that is governed in its practice by New Public Management (NPM). NPM explains the public managerial whose instruments adopt the private sector managerial instruments. In contrast, private sector managerial focuses on gaining profit, particularly in terms of accounting.

The emergence of NPM is triggered by claims that public sector organizations have been deemed so far ineffective, detrimental to the state, and to have low quality work as well as very rigid and less creative compared to private organizations. NPM was first pioneered by Christoper Hood from The London School of Economics in 1991. The origin of this theory is from Europe. NPM was triggered by the inadequacy of the old public management in the 1980s. The form of changes in the traditional public administration to modern public administration is the implementation of decentralization (the transfer of power from the central government to autonomous regions), modernization of public service delivery and devolution (the transfer of power from the central government of a sovereign state to the government at the subnational level, such as states) [1].

NPM has been successfully applied in England and New Zealand where this theory was pioneered. Consequently, NPM is disbursed to various countries, including developing countries, including Indonesia. The emphasis of NPM is the control over the final outcome of government policies, in the form of decentralization, providing service by focusing on customers who are, in this case, the community and the existence of a quasi-market mechanism.

The embodiment of NPM in public sector organizations, enforces the bureaucratic leaders to increase their productivity and choose ways to provide public services that save more on public service costs. The public bureaucracy is encouraged to increase the accountability of public services to the community, restructure the public bureaucracy, improve service performance in public sector organizations, and decentralize the policy making process. The purpose of NPM is to reform public sector organization to be more effective, efficient, and economical [2].

However, the implementation of NPM causes problems among the employees in sector public organization. The substance of structuralism of new public management make public sector organizations seem to be able to "market" the bureaucracy. The bureaucracy is marketed by applying elements of market logic. Public services provided by public sector organizations are considered as transactions in the market that must be purchased by consumers so that public sector managers must always maintain the effectiveness and efficiency of public sector services. The consumers of public sector organizations with weak economic capacity end up getting less public services [3].

The implementation of NPM in Indonesia is unfortunately without any filtering process regarding to the Western values, which also raises new problems. Groups of people who have established economic capacities will have faster access to public services. Further, NPM is nuanced with neo liberalism, which means a state that rejects inhibitions by the Government in the domestic economy.

Neoliberalism is encouraging that state intervention must be reduced and provide the widest possible opportunity for the development of individual business. The demand for 
neoliberalism is that there must be bureaucratic reform or bureaucratic trimming, for example with the existence of an integrated service in public sector organizations in order to realize the widest possible opportunity to do business.

Neoliberalism that is originating from the West [4] has been implemented in Indonesia since 1997 during the monetary crisis. The implementation of neoliberalism has a negative effect on Indonesia. Many of Indonesia's assets are internationally acquired. The government also cannot do much to fight for workers/laborers' wages, because with this neoliberalism, there is no interference from the Government on companies (owners of capital) and workers .

Neoliberalism upholds freedom of work with a dominant direction of secularization by negating God and religion [5]. The advancement of science and technology supports the development of multinational subsidiary companies that are created from neoliberalism. The multinational companies established have a very strong secular and capitalist spirit and they have entered various parts of the world including Indonesia. These giant companies with large capital from the bourgeois [4] was able to buy the large assets of the government and then regenerate multinational subsidiaries. Meanwhile, on the other hand, the government is unable to open its voice on the shrewdness of the actions of multinational giant companies writhing in Indonesian soil. This is all due to the Letter of Intent (LOI) agreement in the Washington Consensus [6].

Public Sector Accounting Standards are inserted with the spirit of NPM. Accounting has failed to understand the substance of value and holiness (God and Religion) which causes village accounting to be dominated by Western accounting. Capitalistic village accounting changes the behavior of village managers who previously managed village finances with the principles of local norms and culture.

Historically, regulation number 5 of 1979 on Village Government, states that efficiency and effectiveness are benchmarks for the success of village governance. Village modernization is also carried out with uniformity in the village government model. Government modernization through the application of accrual accounting is believed to be able to early identify all public service costs. Government modernization with accrual accounting can also assist public sector organizations in making better decisions and can be trusted to improve the performance of public sector organizations. In addition, the hope of implementing this new public management is the realization of good public governance in public organizations.

Public sector organizations in the government sector fulfil the expectation of standard setters to achieve uniformity in the implementation of government accounting. Statute number 71 of 2010 which regulates Government Accounting Standards and Minister of Home Affairs Regulation (Permendagri) No. 64 of 2013 directs the application of accrualbased accounting in local governments.

It is stated that the existing standards in Indonesia is based on the International Accounting Standards Committee (IASC) with the title: Basic Framework for the Preparation and Presentation of Financial Statements [7]. Indonesia has fully adopted Internantional Financial Reporting Standards (IFRS), to be transformed into Financial Accounting Standards (SAK). On the other hand, the implementation of SAK which fully adopts IFRS has not been able to run smoothly in Indonesia [8]. Evidences show that the 
implementation of SAK which adopts IFRS does not reflect the local culture of Indonesia. In fact, the existing SAK tends to have Western nuances [9].

There are several basic concepts of accounting theory: proprietary theory, entity theory, residual equity theory, fund theory, commander theory, investor theory, enterprise theory and syariah theory [7]. The proprietary theory is one of the earliest accounting theories. Proprietary theory teaches that accounting is formed from the basic accounting equation, namely: assets equal to liabilities plus equity. Every increase in income that occurs in a company, of course will automatically increase the wealth of the company owner. The first accounting theory to emerge is deemed appropriate only in companies that have sole ownership or partnership. The next popular accounting theory is entity theory. This theory assumes the separation of owner's wealth from business entities. Hence, it is an entity that must be managed continuously. The next accounting theory is enterprise theory. This theory focuses on the company as a social institutional. This concept is suitable to be applied by large companies that always have to pay attention to their social environment. However, all the basic concepts of this accounting theory are still based on producing the maximum benefit for the owner's wealth.

The article proposes a concept that views the entity as an entity that has a very close relationship with God (vertical relationship) so that the horizontal relationship can be carried out properly. Statute number 6 of 2014 concerning villages explains that a village is a legal community unit, which has territorial boundaries, that are authorized to regulate and administer government affairs. These affairs must be carried out in the interests of the local community based on community initiative, rights of origin, and/or traditional rights recognized and respected in the government system of the Republic of Indonesia.

The holder of power for village financial management is the village head. The village head is assisted by village officials in managing village fund finances. Statute number 113 of 2014 about village financial management confirms that a village should be managed based on transparent, accountable, and participatory principles, and is carried out in an orderly manner with budget discipline [10]. A discourse to redirect village accounting to its purity, away from secularism is much needed. This article hopes to construct village accounting that is embedded with Godliness values.

\section{Method}

This research is a qualitative research, by using postmodernism paradigm. Postmodernism dismantles formal ways of thinking. The reason researchers use postmodern paradigm is because NPM should be dismantled since it is not suitable for village management, and new values must be inserted. One approach of postmodern paradigm is deconstruction [10].

Church reforms carried out by Church Leaders, Martin Luther, are expressed as such:

I cannot and will not recant anything, for to go against conscience is neither right nor safe. Here I stand, I can do no other, so help me God. Amen.

Peace if possible, truth at all costs.

Everything that is done in the world is done by hope.

As long as we live, there is never enough singing. 
God writes the Gospel not in the Bible alone, but also on trees, and in the flowers and clouds and stars.

You are not only responsible for what you say, but also for what you do not say.

Reason is the enemy of faith.

How soon 'not now' becomes 'never'

Let the wife make the husband glad to come home, and let him make her sorry to see him leave.

There is no more lovely, friendly and charming relationship, communion or company than a good marriage.

The church must be reformed according to Martin Luther because of the rejection of the Catholic view of indulgences (freedom from the penalty of sin can be bought with money). Christian values taught by Martin Luther are: love, patience, charity. Martin Luther also wrote the book The Little Catechism, one of which contains the apostolic creed and the sacrament of Holy Communion.

Besides exploring Christian values taught by Martin Luther, an explanation of holiness in accounting and village is constructed using the concept of New Life. New Life, in Christian belief, addressed to humans associated with repentance. A human being who has experienced a New Life, meaning that he/she has left his/her sins and returns to a life that is centered on God alone. The process of purying village accounting is certainly the opposite of what is prevalently dominant in village accounting. At present, village accounting is oriented towards profit growth that can be measured in currency units and the increase in wealth.

New Life as a methodology was used to construct and restore the purity of village accounting, which clearly rejects the impure, as a powerful way to solve problems in the Village Government, to fix the wrong governance system. Bible Verse in 2 Corinth 5:17 said: "so, whoever is in Christ, he is a new creation: the old has passed, the new has come". The expression "in Christ" means a spiritual fellowship, with the Spirit of Christ having a body which is neither mundane nor material but is a light of divine light. Village accounting which implicitly adheres to neoliberalism reflects how a science that upholds freedom, without paying attention to religious values, will bring destruction.

Accounting has opened up space for capitalism to become rulers. Economic Theory and Accounting Theory whose teaching orientation is about profit, emphasizes the very dominat role of the owner of capital in a business entity. The goal is only to increase the profit of the business entity, which of course will increase owner's capital.

New Life as the antithesis of financial management is important to be applied as an active process to encourage society and personal to grow into individuals who experience continuous purification. New Life is to clean one's morality, spirituality and everything that is in the human being himself. The goal is only to make a person repent of his bad behaviour and live again into a new human being who lives in God.

The compilation of The New Life methodology or self conversion for all aspects of the development of village accounting from modernism is then carried out by: first, a historical analysis to explain how village accounting is; second, New Life as a Methodological solution for village accounting. 


\section{Results and Discussions}

The results and discussion are divided into two discussions, first, a discussion of the history of village accounting which was originally sacred to secular, then second, The New Life, as a pure village accounting construction methodology.

\subsection{History of Village Accounting}

History is an important part of the discussion of accounting policies which is a research issue [11]. Early accounting has sacred value in history [12]. Accounting in Indonesia has originally appeared between 1642 until 1945 (before Indonesia's independence). At that time there were still relatively few public accountants. Accounting in Indonesia has existed since the historical times of the Kingdoms in Indonesia. Research on the histography of Indonesian accounting during several kingdom period has been attempted by several researchers [13] [14].

Historically, Indonesia was colonized by the Dutch, Japanese and other colonizers. Various developments in accounting science have also begun to develop in Indonesia along with the influx of colonialists in Indonesia. Since 1642, accounting has been adopted in Indonesia when the Dutch Government issued accounting rules regarding the administration and receipt of cash, accounts receivable, and the budget for garrisons and shipyards in Batavia and Surabaya. Accounting has been implemented in Indonesia in 1642, because there was pressure from the Netherlands to use it [13]. Historical records explain that in 1945, when the Netherlands was urged to return to its home country, Indonesia was freed from colonialism. It was then that Indonesia nationalized Ductch companies. Accounting science was first taught at the University of Indonesia in 1952, adopting Dutch accounting. Since that year, academics in the field of accounting in Indonesia were schooled abroad, due to a shortage of teachers in the field of accounting in Indonesia. However, because Indonesia was unhappy with the nature of the Dutch colonialists, accounting academics in Indonesia were widely schooled to the United States [15]. The United States also provides assistance to Indonesia so that its citizens can attend school in the United States and learn about accounting. Since then, American accounting has been widely applied in Indonesia.

Thie sequence of historical stories needs to be considered carefully. The history of accounting science in Indonesia is influenced by Western nuances due to the impact of Dutch colonialism in the previous period. However, there is something that needs to be underlined from this European nuanced accounting, namely the implied high capitalism in it. This can be seen from accounting teachings that are only centered on the owner of capital. Even in today's neoliberalism era, where globalization of the world is rampant, it is very noticeable that the owners of large capital are the dominant beneficiaries. Large companies such as multinational corporations are able to buy Indonesian domestic assets and changed policies that cannot be interfered by the government, because of their large capital holdings [6]. Even in 2010, Indonesia massively adopted full Indonesian Accounting Standards based on IFRS. In fact, many local companies in Indonesia find it difficult to implement these standards. Along with the implementation of SAK based on IFRS, Government Accounting Standard (SAP) also follows the same path. Cash-based 
accounting was transformed into accrual-based accounting to boost governments' performance. There have also been cases of fraud in the village funds.

\subsection{New Life}

New Life can be an antithesis of the chaos of the world, including accounting and villages. New Life is believed to provide repentance for a human being and free him from the bondage of $\sin$. New Life results not only from true faith and conversion in the Cristian life, but because of God's grace. "Our old man was condemned and killed in Christ's death and in His resurrection" (Roma 6:6).

Martin Luther said that 'the New Life' makes man live in God, fully believes in God, Christ and the Holy Spirit. Martin Luther who is at the same time a figure of Church Reform, declares that God's righteousness is a grace from God which accepts sinners and despair of themselves, but who rejects those who think of themselves as "good". God put on the righteousness of Christ on sinners so that God saw sinners as righteous.

Figure 1. Village Accounting Design:

New Life with Financial Principles of God's Kingdom

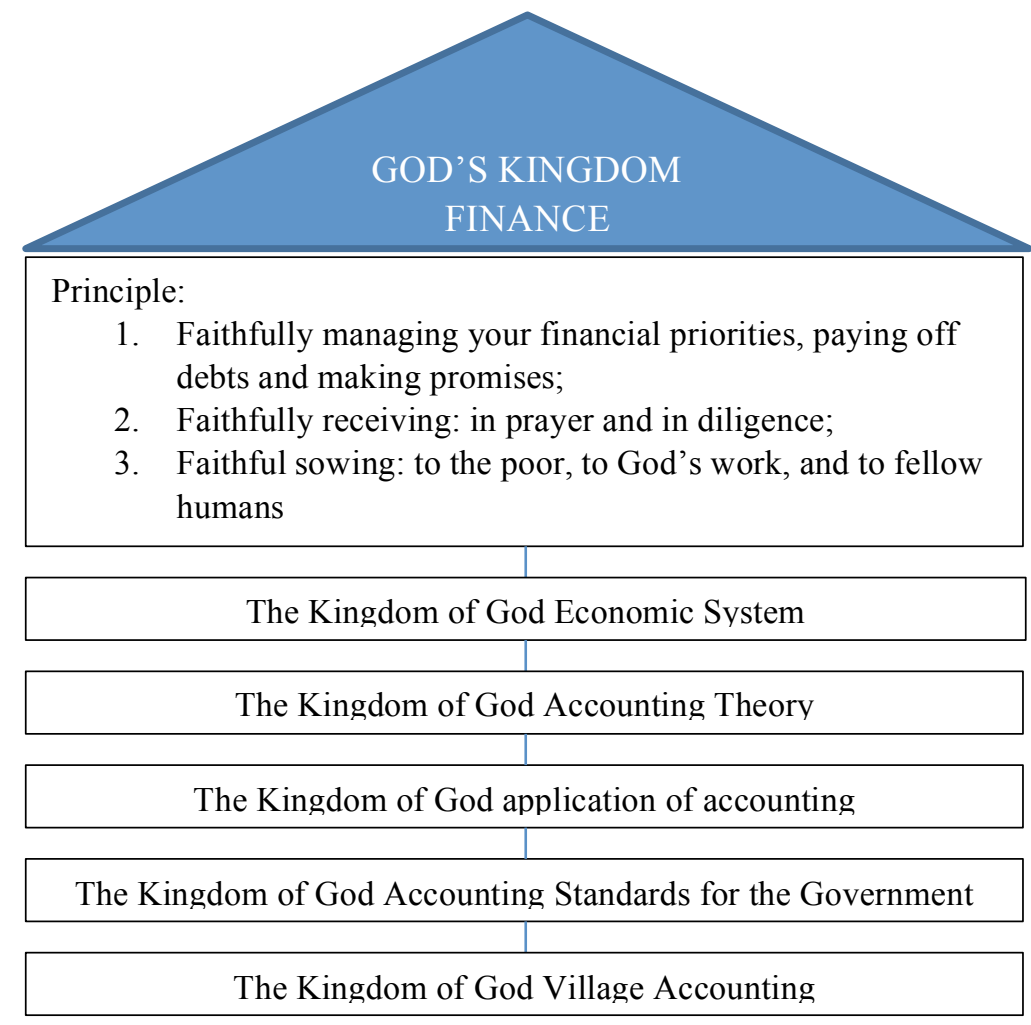

'New Life' in the financial principles of the Kingdom of God can be used for Christian financial management. Figure 1 elucidates the application of village accounting based on the financial principles of the Kingdom of God. The application of village financial management through village accounting in a New Life framework on a national scale has the following principles: loyal to regulations, faithfully accepting and faithful in sowing. In practice, it is the guidance to conduct financial planning, execute financial 
discipline, and carry out responsibility for spending the money owned, as well as to have responsibility for work.

These principles, when put into action, will be able to realize the ideals of the Indonesian people to get out of the confines of capitalism and neoliberalism. The Kingdom of God Village Accounting Theory will become a new pillar to shift the positive accounting theory that has become the mainstream accounting theory.

\section{Conclusion}

The tendency of village accounting in Indonesia that is oriented towards Western accounting is actually not in accordance with the principle of holiness in religious teaching. The Indonesian nation cannot be separated from the history of the development of accounting in Indonesia, which tells us that accounting has existed since the days of the Kingdoms in Indonesia. Even accounting was practiced before Luca Pacioli echoed accounting to the world.

The New Life methodology is the way to open the path to reconstruct village accounting towards its refinement. Village financial management can be done honestly if financial planning, financial discipline, responsibility for providing services, and responsibility for work are executed thoroughly.

The New Life pattern of a human being can be applied in a religious, spiritual and holy life pattern. Humans who have experienced New Life in Christ are no longer enslaved by mammon (wealth, greed desires, dishonesty). Likewise, the management of village finances which is conducted by applying the financial principles of the Kingdom of God, will ensure the managers to have no desire to increase personal wealth, no greed and no more dishonesty. If this is implemented, there will be no more fraud cases committed by financial managers in the village.

\section{References:}

[1] Gruening G. Origin and theoretical basis of new public management. Int Public Manag J 2001;4:1-25. doi:10.1016/S1096-7494(01)00041-1.

[2] Barzelay M. How to argue about the new public management. Int Public Manag J 1999;2:183-216. doi:10.1016/S1096-7494(00)89035-2.

[3] Lynn LE. A critical analysis of the new public management. Int Public Manag J 1998;1:107-23. doi:10.1016/S1096-7494(99)80087-7.

[4] Jupe R, Funnell W. Neoliberalism, consultants and the privatisation of public policy formulation: The case of Britain's rail industry. Crit Perspect Account 2015;29:6585. doi:10.1016/j.cpa.2015.02.001.

[5] Mulawarman AD. Tazkiyah: Metodologi Rekonstruksi Akuntansi Pertanian. Assets J Akunt Dan Pendidik 2019;8:78-93. doi:10.25273/jap.v8i2.4656.

[6] Mulawarman AD. 2024 Hijrah Untuk Negeri: Kehancuran atau Kebangkitan? Indonesia Dalam Ayunan Peradaban. Kesatu. Jakarta: Ngapurancang; 2016.

[7] Mulawarman AD. Akuntansi Syariah: Teori, Konsep dan Laporan Keuangan. Jakarta: E Publishing Company; 2008.

[8] Mulawarman AD. Akuntansi Pertanian: A Prophetic Legacy. Jakaera: Yayasan Rumah Peneleh; 2019.

[9] Kamayanti A. Akuntansiasi atau akuntansiana? Memaknai Reformasi Akuntansi Sektor Publik di Indonesia. J Akunt Multiparadigma 2011;2:531-40. 
[10] Kamayanti A. Metodologi Penelitian Akuntansi: Pengantar Religiositas Keilmuan. kesatu. Malang: Penerbit Peneleh; 2020.

[11] Mulawarman AD. Metodologi Konstruktif Riset Akuntansi: Membumikan Religiositas. 1st ed. Jakarta: Ngapurancang; 2016.

[12] Harari YN. Homo Deus: a Brief History of Tomorrow. Harvill Secker; 2015.

[13] Sukoharsono EG. The genesis of accounting in indonesia: the dutch colonialism in the early 17th century. Indones J Account Bus Soc 1993.

[14] Lutfillah NQ. Gayatri: Akuntan Majapahit. Malang: Penerbit Peneleh; 2021.

[15] Mulawarman AD, Kamayanti A. Towards Islamic Accounting Anthropology: How secular anthropology reshaped accounting in Indonesia. J Islam Account Bus Res 2018;9:629-47. doi:10.1108/JIABR-02-2015-0004. 
This page is intentionally left blank 